\title{
Chapter 3 \\ In whose name? \\ On statues, place and pain in South Africa
}

\author{
Alude Mahali
}




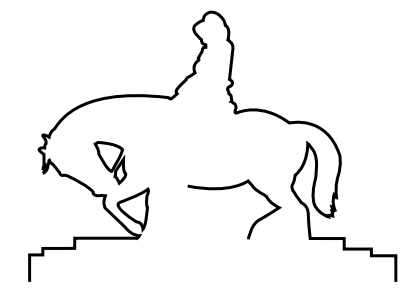

It takes a lot of work to silence silent objects. (Cole 2012)

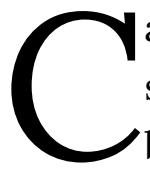
alls for the removal or demolition of colonial and apartheid statues and monuments across the South African landscape has been the subject of dissension. This chapter proceeds from the national discussion around statues and representation starting with the performative act that catalysed the current dialogue about colonial and apartheid statues, namely, the \#RhodesMustFall campaign. Through discourses of pain, place, memory and history, this chapter probes what is commemorated and explores the tensions around where that commemoration takes place. To queer place is to really look closely at what the decolonisation of buildings and of public spaces could look like and how this might aid in democratising access. What we are sensing now is that it is not enough to build new sites of public history and memory without problematising the existing objects of cultural heritage that no longer represent the values of a democratic South Africa - the statues and monuments of imperialists. This chapter asks how people make sense of their interaction with place and so-called objects of cultural heritage and illustrates why, in a South African context, statues and monuments are not just inanimate, innocuous things. They are loaded with meaning, histories and the pain of a traumatic past.

\section{Background: from past to present}

The year 2015 was a volatile and transformative year for South Africa's higher education institutions, catalysed in part by student protester, 
Chumani Maxwele who - in the second week of March 2015 -- hurled faeces at the statue of Cecil John Rhodes ${ }^{1}$ that stood at the University of Cape Town's (UCT) main Rondebosch campus. This single act, motivated by persistent concerns around systemic violence and structural inequalities in higher education and society broadly, also sparked debates around the contentious place of colonial and apartheid statues and monuments in contemporary South Africa. Maxwele's performative act supposedly set into motion the \#RhodesMustFall (RMF) campaign which then galvanised a series of national student activist movements including Fees Must Fall, Disrupting Whiteness (University of Cape Town), Rhodes So White and the Black Students Movement (Rhodes University), Transform Wits (University of Witwatersrand), the Open Stellenbosch Collective (Stellenbosch University) and Black Thought at the University of Johannesburg. Other universities joined the protest simply under the overarching \#FeesMustFall banner. The rage being expressed and the point being made by the students is that the existential struggles which shape South African life are no longer limited to the individual's experience, but that a magnifying glass is now being held up to embedded structural inequalities in the university that reflect society broadly (Keet, Zinn \& Porteus 2009, 114).

The student movements also prompted conversation on the roles of intersecting identities (race, class, gender and language) in students' perceptions, experiences and agency in creating opportunities or being 'shut out' while at university. The message to the institutions and the government is very clear: things can no longer carry on as they have, as the current modes of operation within the universities are perceived as being oppressive, stifling and unsupportive. Further, the traditions, values and practices that have been disguised or explained as 'institutional culture', are exclusionary in manners so pervasive that they permeate the students' everyday reality in the institution (especially in historically white institutions). The issue of higher 
education's oppressive financial schemes and lack of transformation in particular, were identified as catalysts fuelling the national student outcry. Other issues that prompted the protests included the lack of racial representation among faculty at historically white universities, the exclusion of African narratives and experiences in curriculum, the historical edifices and cultural heritage objects (statues, monuments, building names and artworks) whose meanings have changed in a democratic South Africa, and the outsourcing of student residence and low income university workers.

A week after Maxwele's inciting act at UCT, students at the University of KwaZulu Natal (UKZN), in solidarity, defaced the statue of British King George V that stands at the university's Howard College campus in Durban (Manda 2015). Suddenly statues were at the forefront of national discussion and, in a ripple effect, incidents of similar destruction were occurring throughout the country. The statue of a soldier on a plinth at the Uitenhage War Memorial was defaced and set on fire on 2 April 2015 (DeSwardt 2015). On 6 April (and again on the $\left.11^{\text {th }}\right)$, a statue of former president of the South African Republic Paul Kruger that stands prominent in Church Square, Pretoria was defaced with green paint (Khoza 2015). A day later, the statue of a kneeling solider was pulled to the ground in Port Elizabeth (Spies 2015). On 9 April the statue of first South African Prime Minister Louis Botha, was splattered with red paint in Cape Town (Capazorio 2015). The following day a statue of Queen Victoria was defaced with paint in Port Elizabeth (News24 2015). In Pretoria on 11 April, a statue of Marthinus Pretorius (the first president of the South African Republic) was vandalised in front of City Hall (Lindeque 2015). On 13 April, the statue of Andrew Murray (the son of a Dutch Reformed Church missionary) was vandalised in Wellington (Raborife 2015). Finally, on 20 April 2015, the bust of Stephanus Schoeman (former state president of the South African Republic) was splattered with white paint in Polokwane (Mabeba 2015), the same day that the Anglo Boer War memorial was also defaced with white paint in East London (Linden, 2015). 
Before the Rhodes statue became a target at UCT in 2015, there were only a few reported incidents of the defacing or destruction of statues since 1994: for example the statue of Steve Biko was defaced twice shortly after it was unveiled by President Nelson Mandela in September 1997 (allAfrica, 2015). The crash of apartheid leader J.G. Strijdom's head in 2001, and the repeated vandalising of Paul Kruger's statue, both in Pretoria, come to mind as well. The other incidents came in 2005 and 2006 when, in September 2005 the statue of King Makhado in Limpopo was defaced and then later in July 2006, the statue of Chief Tshwane was vandalised in Pretoria and painted with the colours of the old South African flag used by the apartheid government (Hlatshwayo \& samaYende 2005; Nthite 2006). What these three historical figures have in common is that they are black Africans and all three statues were defaced at least 10 years ago, probably by disaffected members of right-wing white supremacist movements. The Biko incident occurred three years after the democratic dispensation in 1994, when the country was still struggling with its rebirth, and the destruction of the King Makhado statue came soon after the renaming of a town in Limpopo Province from Louis Trichardt to Makhado. The statue of Chief Tshwane was defaced with the old apartheid flag after there were talks that the statue would replace the existing one of Paul Kruger on Church Square. Evidently there was a faction of the population that was not ready to accept the ushering in of a new inclusive democratic age that would mean letting go of some of the polarising relics of the past, which had come to stand for different things in the present.

Although the colonial and apartheid figures listed above were memorialised as part of South Africa's history - several of whom served as rulers or benefactors - they also represent colonial and apartheid histories, as symbols of racism and genocide and one could argue, that their continued presence reproduces coloniality as representations of "the 'metaphysical empire' that have outlived the 'physical empire"' (Ndlovu-Gatsheni \& Zondi, 2016:4). One could also argue that the sites at which these deliberate acts of vandalism have taken place, have become "legitimate sites of decolonial struggle" (ibid.). From this 
thought, I started to question the particularity of this contemporary moment. Is it that the presence of these statues always bothered us, but we have not yet been able to articulate the reasons why? Is it that we have arrived at a new place of conscientisation as a result of the slow pace of transformation in South Africa? Is it that we were focused on other issues at the start of democracy and can now turn our gaze to the statues and monuments we want because this is this generation's predicament? What is significant about this present moment? Or is it simply that we have now called this particular issue up to importance?

If we reconstruct the past according to our current views then the rewriting of individual biographies, the creating of new myths, or the reviving of old wounds and resentments is expected (Subrt 2012, 37). In every contemporary moment, our perceptions, understanding of and ideas about the past are constantly changing. New realisations, experiences, knowledge about the present can even influence the way we perceive the past, causing us to look at history and the past in different ways: this is the meditative decolonial state we currently find ourselves in.

Add to that already subconscious force the immediacy of history's grip, when the past is publicly memorialised through oppressive historical figures, who continue to haunt the contemporary landscape in prominent urban spaces throughout the country.

\section{Images of the past haunt the present}

Who we choose to commemorate and how we choose to remember them is complex, particularly in the case of memorialised subjects made into symbolic objects of history (Grunebaum 2001, 198). I would add, to who and how we choose to commemorate, where we choose to commemorate them. Perhaps place has not been privileged as much as the 'who'. For instance, when a cultural and political heritage site such as Robben Island becomes a project through which the government exercises its commemorative agenda, claiming to remember and celebrate the past through inclusive "multiculturalism", we start to see 
an attempt at creating "new public histories" (Grunebaum 2001, 199). Even this is problematic because most South Africans do not have the material means to visit a site like Robben Island. Nevertheless, Robben Island has had many uses prior to UNESCO declaring it a world heritage site in 1999. It is an example of a monument built from an existing place, history and structure whose meaning changed with its 'rebranding'. This is different for example from the pre-1994 monuments that remain largely uncontested and unchanged, even in a democratic South Africa. Examples of these existing monuments are the Castle of Good Hope (the oldest surviving building in South Africa, built between 16061679) in Cape Town (SAHO 2011), the Honoured Dead Memorial (1904) in Kimberly which remembers those who died defending the town during the 124 day Siege of Kimberley in the Anglo-Boer War of 18991902. Interestingly, the Honoured Dead Memorial was commissioned by Cecil John Rhodes. Scenically bordered by Table Mountain, the Rhodes Memorial (1912) in Cape Town was built in remembrance of Cecil John Rhodes who contributed a great deal to the development of the subcontinent. The National Women's Memorial (1913) in Bloemfontein was erected in memory of the women and children who died during the Anglo-Boer War, at the hands of the British, but excluded any mention of black victims. The Huguenot Monument (1948) in Franschhoek was built to celebrate the influence of the French in South Africa. The Voortrekker Monument (1949) in Pretoria commemorates the white Pioneer history of Southern Africa, especially the history of the Afrikaner. This was later followed by the Winburg Voortrekker Monument (1968) in the Free State, in honour of Winburg as the first Free State town established by the Voortrekkers. The 1820s Settlers Monument in Grahamstown was built to commemorate the contributions made by English-speaking settlers to South Africa - in particular - the introduction of the English language and the concept of democracy (SouthAfrica.com). Diggers' Fountain in Kimberley (1960) was created in honour of past and present diamond miners and a bust of Sir Ernest Oppenheimer shares the same rose garden site as the fountain (SouthAfrica.info 2015). These are just a few examples of many. 
These pre-1994 monuments are quite different from the monuments built specifically to commemorate people and events post-1994. For instance the Bisho Massacre Memorial (1997) in the Eastern Cape - a monument that commemorates slain anti-apartheid activists (SouthAfrica.info 2015.). Similarly, the Hector Pieterson Memorial (2002) in Johannesburg commemorates the role of the country's students in the 1976 uprising against apartheid: The Freedom Charter Monument (2005) is a piece of land meant to memorialise the occasion on which some 3000 members of resistance organisations gathered to imagine the Freedom Charter (SouthAfrica.info 2015). Heroes' Park (2001) in East London was built to honour South Africa's struggle heroes and to celebrate the country's freedom and cultural diversity. Interestingly, Heroes' Park also incorporates the German Settlers Monument, which honours the German families who arrived in East London between 1856 and the 1870s (SouthAfrica.info, 2015). The Slavery Emancipation Monument (2004) in Elim was built in memory of emancipated slaves who were harboured at Elim in the Overberg, Western Cape (SouthAfrica.info 2015). The Gallows of the Pretoria Central Prison opened in December 2011 in memory of the political prisoners who were executed between 1967 and 1989 (SouthAfrica. info 2015). All these monuments are billed as sites that "celebrate our freedom' and 'cultural diversity' and honour those whose lives were lost trying to gain that freedom.

Two things are curious about the pre-1994 and post-1994 monuments; the most obvious is that pre-1994 statues were of white men and women, while the post-1994 monuments are typically in celebration of black men and women. The post-1994 sites were built in the spirit of "creating new public histories" and claim to foster "inclusive multiculturalism". Can the pre-1994 monuments also make claims to 'celebrate freedom and foster inclusive multiculturalism' as the post1994 monuments do? The other curious thing is the geographical sites and spaces on which these different monuments are located. Many of the pre-1994 monuments are in scenic suburban landscapes surrounded by the natural beauty of South Africa. Is it important to 
have these colonial and apartheid monuments still sitting alongside more contemporary ones - not only symbolically but geographically?

What we are sensing now is that it is not enough to build new sites of public history without problematising the existing objects of cultural heritage that no longer represent the values of a democratic South Africa. It is not enough to focus on "new public histories" without addressing the remaining material public histories of old; the statues and monuments of imperialists. This is not an easy task, as the last three years have taught us.

The students at UCT were victorious in their protest efforts as the statue of profiteer Cecil John Rhodes was ceremoniously removed on 9 April 2015. At UKZN however, the statue of King George V still remains on the campus but it now stands damaged, splashed with white paint and bearing the words; "end white privilege", "you do not represent us" and "symbols must fall" amongst other messages. There has been no news as to whether or not the other statues that were defaced, in other parts of the country, have been toppled. However, in a shocking move in February 2016, some RMF members removed and burned several historical artworks that hung in university residences at UCT. According to the activists, these artworks and photographs represent white colonial and apartheid oppressors and it should not matter that they were donors to the university: their presence on the walls of an African university is painful and traumatic. The drastic act of arson is said to have cost the university millions of rands in damages and in the melee, students also burned anti-apartheid works by prominent black artists. This came after the RMF members erected a makeshift shack on the main campus, aptly named, 'Shackville' in response to the lack of housing and student residences at UCT. Despite contention, the RMF campaign received widespread national and international support, but of course opinions about what should happen to colonial and apartheid statues in South Africa differ. Anecdotally, there are those who agree that the Rhodes statue (and other statues like it) should fall; those who argue that the statues should remain as evidence of the 
country's history; those who argue that they should all be removed and placed in national museums; those who feel as if the statues should remain if they are explained and those who are indifferent. All this background is to say, now, sites memorialising historical statues have become charged sites of contestation.

\section{On Decolonising Spaces}

Teju Cole, writing on the 2012 destruction of the sacred tombs/ mausoleums of Timbuktu, maintained: "it takes a lot of work to silence [these] silent objects", for the reason that statues are not just inanimate, innocuous things. Statues are loaded with meaning, histories and the pain of a traumatic past. Cole recognises this by asserting: "Images are powerful. They can bring people into such a pitch of discomfort that violence ensues, and iconoclasm carries within itself two paradoxical traits: thoroughness and fury" (Cole 2012). Analysing the complexity of iconoclastic aggression, Cole identifies "politics, struggles for power, the effort to humiliate an enemy" as common historical reasons for iconoclastic acts (2012). Cole is making the subtle argument that the creators of images and the iconoclasts share the same psychological drive - both are obsessed with the power of the icon. Cole's words; 'discomfort', 'violence' and 'fury' point to an anxiety around symbols and objects that cannot be denied and in South Africa, anxiety around statues points to the veracity of black pain. The pain is not always an immediate obvious pain happening in the 'now'. Sometimes the pain is about the past, is buried in history, in memory, in lived experience and autobiography, and yet is felt in the present. The pain is not all now and it is not always painful, sometimes it is hidden by the beauty of scenic garden surrounds and towering city buildings, at times it is revealed through the fiery, ugly and grotesque, other times it subsides and sometimes it is not noticeably there at all but there is always an element of residue; the fragments of pain left in the South African consciousness and landscape. Achille Mbembe, acknowledges this pain when he warns that wanting to hang on to these statues can feel like "provincialism and nostalgia for a shameful and costly past" (Mbembe, Samuelson, Nuttall \& Musila 2011). 
Mbembe is clear in his assertion that Rhodes no longer belonged on the UCT campus, stating that the Rhodes Statue "and those of countless others who shared the same conviction - has nothing to do on a public university campus 20 years after freedom" (Mbembe 2015, 3). That taking the statue down should be not considered "erasing history" - despite the deeply problematic rhetoric that Rhodes "donated so much money" and "bequeathed his land" to the university - with little inquiry into how he amassed his wealth in the first place (Mbembe 2015, 3). Instead Mbembe holds that bringing Rhodes's statue down is one of the many legitimate ways in which we can, today in South Africa, "demythologize that history and put it to rest - which is precisely the work memory, when properly understood is supposed to accomplish" (Mbembe 2015, 3). There are many places in South Africa that are still palpably occupied by the lingering feeling of whiteness, that is, that black bodies do not belong in such spaces. Crucially Cape Town is often jokingly referred to as the 'Europe of Africa' that

obsessively clings to its anachronisms, its ossified forms of spatial segregation, its statues, even its street names, and today to the hard edges of its 'soft apartheid'. (Mbembe et al. 2011)

Add to this already complex "scandal of beauty", ${ }^{2}$ the statue of a colonial oppressor on an African university campus, then it is no wonder students feel as though they are being stifled by white ideals. Rhodes memorialised, becomes a mythologised figure that perpetuates the feeling that everything originates from him:

The demythologizing of certain versions of history must go hand in hand with the demythologizing of whiteness. This is not because whiteness is the same as history. Human history, by definition, is history beyond whiteness. Human history is about the future. Whiteness is about entrapment. Whiteness is at its best when it turns into a myth. It is the most corrosive and the most lethal when it makes us believe that it is everywhere; that everything originates from it and it has no outside. We are therefore calling for the demythologization of whiteness because democracy in South Africa will either be built

2 From the Cape Times article of the same name. See Mbembe et al (2011). 
on the ruins of those versions of whiteness that produced Rhodes or it will fail. (Mbembe 2015, 3)

Mbembe proposes that the statue of Rhodes and the statues of other racist imperialists that are scattered across the South African landscape be placed in museums. At the same time he problematises the museum which he feels has not yet received the critique it requires as an institution, in other words, a good question is also, what is in South Africa's museums and why? (Mbembe 2015, 4). This question challenges what is archived and who decides what is historicised and why.

Really the decolonisation of African minds, places and institutions does not mean the dismissal of a troubled past, or a negation of history and its figures, but rather it is about "acknowledging, debating and encouraging critical scholarship on how exactly colonialism, settler colonialism and apartheid" have formed and continue to influence the thought, geography, languaging and customs of modern day South Africa (Pillay in Gatsheni-Ndlovu 2016, 3). The need for decolonisation is becoming more and more pressing in South Africa because the consequences of not recognising the damage colonisation has done to South African territory, the South African body and mind and South African epistemology, is part of the reason why youth in South Africa have unified to protest and quite literally, set the country on fire. It took young people to examine the symbols and images around them to say 'these ideals and versions of history do not represent me and make me feel as though I do not belong here'.

\section{On Decolonising Symbols}

Symbolic interactionism as defined by Herbert Blumer (1969) is the fundamental idea that people act toward things based on the meanings they have for them, that these meanings are arrived at as a result of interpretive processes and social interaction with others (Blumer 1969, 2). Snow introduces four broader principles where he feels Blumer's triad is too narrowly centred on meaning and interpretation: the principle of interactive determination, the principle of symbolisation, 
the principle of emergence and the principle of human agency (Snow 2001, 368). The principle of emergence is pertinent here because it focuses attention on the unfamiliar side of social life and its dynamic character which means 'emergence' looks at the potential for change (not only structural societal change but also change associated with meanings and feelings) (Snow 2001, 372). Emergence is about the

processes out of which new, novel, or revitalized social entities, or cognitive and emotional states, arise that constitute departures from, challenges to, and clarifications or transformations of everyday routines, practices, or perspectives. (Snow 2001, 372)

Emergence is the idea of the altered 'new' and is a particularly useful concept in the context of social movements; this new generation organises with youthful vigour reviving the strength of past liberation strategies (for example crowd-pulling marches to parliament), assumes drastic tactics (for example throwing faeces), with new disputes (for example RMF) and new ways of taking collective action (for example erecting a shack on the university campus as a symbol of the displacement students face as a result of exorbitant residence accommodation fees). What emerges are not only institutional and legislative gains (typical results of social movements), but also cognitive and affective changes (socio-political conscientisation and identity politics). These changes affect not only how we view ourselves and the places we occupy, but our views of other groups and our relationships to/with them.

In Contemporary Sociological Theory (2008), Johnson cites Mead, in explaining Symbolic Interactionism as the close relationship between the psychological processes "whereby people make sense of their environment and their interaction with one another" and the alliance between people as they try to develop collective understandings of the positions in which they find themselves (in Johnson 2008, 110). Contemporary symbolic interactionism also takes into account how one's self-image develops through awareness of the perceptions of others, for example the works of W.E.B. Du Bois or Toni Morrison show how the self-images developed by African Americans 
(and no doubt other members of dis-privileged minority groups) reflect their ongoing struggles to resist the prejudice and discrimination they experience on a daily basis in interacting with majority group members. (Johnson 2008, 110)

In South Africa, self-image and perception emerges as a result of a majority dis-privileged group interacting with a minority privileged group. It is only when individual meanings and readings submit to extensive change that institutional transformation occurs, which then has the potential to change subsequent interactions at the micro level (Johnson 2008, 111).

All symbolic interactionists emphasize the micro level linkages between the subjective consciousness, interpersonal interaction, and identity formation, as well as the symbolic and socially constructed nature of the larger social world. (Johnson 2008, 111)

In this case the linkages occur between the individual student, the university space, the objects of cultural heritage and artworks (buildings, photographs, statues, plaques and paintings) and other people at the university (administration, faculty, support staff, other students). Therefore, decolonising the universities must start with reconstructing both these linkages and the public spaces they occupy. Transforming public spaces includes a change of those colonial names, statues, iconography and other symbols that continue to uphold white supremacy (Mbembe 2015:5). The act of de-imperialising public buildings and spaces becomes, in some manner, about democratising access:

But when we say access, we are also talking about the creation of those conditions that will allow black staff and students to say of the university: "This is my home. I am not an outsider here. I do not have to beg or to apologize to be here. I belong here" [...] It has nothing to do with me having to assimilate into a culture that is not mine as a precondition of my participating in the public life of the institution. It has all to do with ownership of a space that is a public, common good. (Mbembe 2015, 5) 
In decolonising and transforming the significance of place in South Africa - in spite of histories of racial oppression - we get to acknowledge, question and reimagine our history, and this is an affirming act of selfdetermination.

\section{Place and Memory}

In Space and Place (1977), Tuan explains that ideas concerning place are multifaceted in adult human beings because they grow out of individual and shared experiences. He sees place as a pause in movement that makes it possible for us to endow place with value. Place, to a child for instance, is a great and to some extent, inert type of object. Place then begins to acquire profound significance for the child through the steady accrual of sentiment over the years. Every item in one's bedroom or even a stain on the wall tells a story. Similarly, every piece of art, photograph, statue, monument at a university, tells a story, tells a particular history. For Tuan, captivating or painful images of the past are evoked not only by the intact edifice, which can only be seen, but equally by its workings, parts and fixtures, which can be touched, heard and smelled as well. Therefore, despite having to constantly defend their position, RMF insists that their movement is not solely about a statue falling or even the actual edifice. Memory entwines its charms in lesser, more recognisable things, as Kevin Quashie reminds us in Black Women, Identity and Cultural Theory $(2004,7)$...

... memory crystallizes and secretes itself at a particular historical moment, a turning point where consciousness of a break with the past is bound up with the sense that memory has been torn- but torn in such a way as to pose the problem of the embodiment of memory in certain sites where a sense of historical continuity persists.

Escobar recognises that place, body and environment integrate with each other, "that places gather things, thoughts and memories in particular configurations ..." $(2001,143)$. Site and memory then, are inevitably intertwined; particular sites may supply an excess of possible meanings. At the same time it is the site's very same assault on all ways 
of perception (sight, sound, smell, touch and taste) that make it powerful as an underpinning of memory, as a thread where one strand ties in another (Creswell 2004, 86). A site can act as a container of experience that contributes effectively to its inherent memorability. An attentive memory connects impulsively with place, finding in it features that support and correspond with its own activities. So what happens - as in the case of historically white universities for instance - when you do not find these features that reinforce your sense of belonging?

Sites of memory are themselves a process, a dynamic location of collective and individual knowledge constantly refiguring, emitting and tearing. Sites of memory are described as having corporeal qualities, for example, Verderey (1999) terms physical attacks on monuments as "calculated acts to despoil their sacred character in order to bring them into the human realm" (cited in Kros 2015, 154). This is reinforced by Chumani Maxwele,

"quoted by a fellow student as saying that he wanted the statue to feel 'ashamed, the same way he [Maxwele] feels ashamed that these faeces [sic] are in his living environment"'. (Boroughs cited in Kros 2015, 154)

In this manner, Maxwele is almost converting the statue's representation from "untouchable icon to sentient human being" (Boroughs 2015). Kros makes the argument that even the word 'Fuck', painted in white graffiti on the base of the Rhodes statue or the phrase 'end white privilege' emblazoned on King George the V's chest for instance, give the statues a "human quality" adding that in the RMF context, it might be suggested that even the photography and social media activity also contributed to the students' efforts to demystify the statue (Kros 2015, 154).

Demystifying the statue in this manner is, as UCT student Kealeboga Ramaru observed, another way to say "look this is our space too, and we deserve to be here"' (cited in Kros 2015, 155). This act of demystifying articulates "a cry for belonging" (Shringapure 2015). Maxwele, on the RMF campaign echoes: "It is a black cry, a cry of the workers, the cry of the staff and a cry from the students" (Bashton 2015). The cry is about the 
unending state of recovery we seem to be in, in post-apartheid South Africa. The symbolic appropriation of 'the cry' is powerful because it is a life-saving expression of pain. Addressing the statue of Rhodes directly embodies an attack against the continued exercise of power his legacy has over their environment and lives, a legacy that memorialises a history of specific power relations. The act of demystifying statues is an expression of the country's collective and individual anger, of collective and individual grief. The same act creates a 'living' thing to assign pain to, to put anger outside of ourselves and onto something else and to assign culpability when we are no longer being heard.

But then again creating public memory spaces that are significant and all-encompassing in a traumatised South African landscape is a difficult task: "such spaces are affected by a multitude of forces: individuals, groups, institutions, history and culture among others" (Leibowitz 2008 , 5). How do we create spaces where the past is acknowledged but not at the expense of individuals' senses of history and contemporary positionality? For this to happen, "there must be a deliberate shift away from colonial/Apartheid notions of what constitutes the past" (Leibowitz $2008,19)$. There must be recognition of the publicness of the space that these statues occupy and of collective memory (also understood as social or cultural memory), that is, widely shared perceptions of the past that can no longer be trivialized or ignored (Leibowitz 2008, 4).

Leibowitz further posits that sites of memory can be material, symbolic and functional:

"While memory exists on both a personal and national level, memory space is constructed and maintained in order to facilitate a particular ideology or to sustain a national narrative" $(2008,5)$.

This is significant because in the past, the national narrative was constructed from a colonial and apartheid perspective and so it makes sense that now we are calling to see reflected in our statues and memorials "a contemporary form of memory practice born out of a more locally-generated aesthetic and meaningful to an [South] 
African population" (Leibowitz 2008, 5). Perhaps we will, after many years, decide that the Western tradition of commemoration is neither relevant nor necessary in an African context and we will think of new ways to commemorate people and observe events in an anticipated non-patriarchal, robust and democratic society because, as Subrt reminded us earlier, in every contemporary moment, our ideas about the past are constantly changing. As a result, it is inevitable that in future moments our perception and understanding of what we want to see memorialised and how it should be memorialised will change. For now though, our longing to see worthy monuments is a moment we are resting in.

\section{The new South Africa}

After the dawn of the democratic dispensation, Nelson Mandela remarked:

During colonial and Apartheid times, our museums and monuments reflected the experiences and political ideals of a minority to the exclusion of others ... having excluded and marginalised most of our people, is it surprising that our museums and national monuments are often seen as alien spaces? When our museums and monuments preserve the whole of our diverse heritage, when they are inviting to the public and interact with the changes all around them, then they will strengthen our attachment to human rights, mutual respect and democracy, and help prevent these ever again being violated (quoted in Corsane 2004, 6).

Post-apartheid South Africa was branded 'the new South Africa' as a way to give a name to the huge political shifts occurring as well as to promote hope for the anticipated cultural and social change. Memory becomes critical in social theorising and critique during such transitions: it was critical for everyday South Africans to come to terms with what was done to them or in their name. But we also need new names and to appreciate the significance of the situatedness of history in the processes of transformation which characterise contemporary South Africa. 
The Truth and Reconciliation Commission (TRC) was perhaps the most visible public exhibition of engaging the human rights abuses caused by the apartheid government (McEachern 1998, 499). The TRC uncovered black pain in a way that had not been done before. It rendered black pain visible. How do we begin to think about other public ways we can work through pain, demystify place, interrogate iconography and express individual and collective memory in this country? An example of a project that attempted to both remember and give individuals agency over their own painful pasts was the Western Cape Action Tour Project (or WECAT). WECAT took people on walkabouts through the townships of the Cape Flats, while participants narrated the stories of their lives and their communities. In this way

... the project facilitated encounters that not only promote the remembrance of the social and political heritage of these communities and of the enduring effects of this heritage on people's lives and lived environment, but also evoked both new forms of socioeconomic marginalization contoured by persisting systemic oppression as well as new possibilities for change. (Grunebaum 2001, 203)

The tour facilitators (often former activists) then had the opportunity to fill the gaps missed by the TRC and include narratives that do not fit the "public version of Robben Island's public historical narrative of transcendence, triumph, redemption, and reconciliation" (Grunebaum 2001, 203). In this way, the past continues to live and the ephemeral nature of this contemporary moment and the sites we move through, become transformed and "imbued with multiple meanings as stories are told in, about and through them" (Grunebaum 2001, 203). In the same manner, statues like these contested sites are not in dead spaces but they are always in dialogue with history and the present. The statues need to be problematised and probed, and we need people to speak around and about them and the places that they occupy. 


\section{Afterthoughts}

The removal of the Rhodes statue, while largely symbolic, has been an appropriate rallying cry by which to tangibly address the practical implications of transformation and decolonisation and to re-imagine what the role and function of an African University should be. The success of the removal of the statue will illustrate an important step in the ability for social movements under these rallying points, to effect change physically in their environment. This process of physical change in the university space will begin to provide material shape to the changes taking place in post-apartheid South Africa. Moreover, toppling Rhodes and the RMF campaign in general, were not intended (at least by its initiators) to deny a particular history, but the process of physical change prompted by the statue's removal raises questions around the names we give to the spaces we occupy and helps us pay closer attention to the symbols and images that we are confronted with as we navigate these public spaces. So the issue becomes, not the statue itself, but how we as a society look at symbols of the past and understand the various ways in which those symbols interact with who we are now, and the places we traverse in our day-to-day lives. "Monumental symbols, like statues have a rhetoric. These rhetorical functions or meanings shift as society shifts and changes" (in Crowley 2007, 56), and we are now in a time where these meanings have definitely shifted and demand clarification.

Many of the UCT students recognised that the historical narrative of which the statue was the most conspicuous feature in their immediate environment, continues to exercise power over the present. As Teju Cole reminds us in the opening of this paper: "It takes a lot of work to silence silent objects" (2012). The presence of these statues topographically shapes silence. If they are to remain then serious conversations around their place and meaning need to be had. This means a recognition that symbol, place, memory and sentiment are inextricably linked. 
As Teju Cole so poignantly articulates: “That which doesn't speak dumbfounds. After all, who can tell what such objects are thinking? Best to destroy the inscrutable, the ancient, if one is to truly usher in a pure new world" (Cole 2012). To decolonise space then, means to dismantle that which continues to reproduce and promote whiteness in favour for ushering in a new order that represents the values of a democratic South Africa for all.

\section{Bibliography}

Kanhema, Newton.

South Africa: Vandals Deface Biko Statue in East London. allAfrica, 2 October, 1997. Accessed 26 October 2016, http://allafrica.com/stories/199710020070.html

Bashton, J.D.

UCT in politics: Rhodes Must Fall, 20 March, 2015. Accessed 8 June 2015, jdbashton.com/uct-inpolitics- rhodes-must-fall

Blumer, Herbert.

1969. Symbolic Interactionism: Perspective and Method. Englewood Cliffs, NJ: Prentice Hall.

Boroughs, Don.

Why South African students say the statue of Rhodes must fall, 2015. Accessed

18 May 2015, kbs.org/news/2015/mar/28/why-south-african-students-sayrhodes-must-fall

Capazorio, Bianca.

Statue outside Parliament defaced. Timeslive, 9 April, 2015. Accessed 26 October 2016, https://www.timeslive.co.za/politics/2015-04-09-statueoutside-parliament-defaced/

Cole, Teju. 2012.

Break it Down. The New Inquiry, 3 July, 2012. Accessed 21 April 2016, https:// thenewinquiry.com/blog/break-it-down/

Coombes, Annie E.

Monumental Histories: Commemorating Mau Mau with the Statue of Dedan

Kimathi. African Studies 70, no. 2(2011):202-223. 
Corsane, Gerard.

Transforming Museums and Heritage in Post-Colonial and Post-Apartheid South Africa: The Impact of Processes of Policy Formulation and New Legislation. Social Analysis 48, no. 1(2004).

Creswell, Tim.

Place: a short introduction. Malden, MA: Blackwell Publishing LTD, 2004.

Crowley, John.

Constructing Famine Memory: The Role of Monuments. In: Heritage, Memory and the Politics of Identity: New Perspectives on the Cultural Landscape, edited by Niamh Moore and Yvonne Whelan, 56-68. England: Ashgate, 2007.

De Jorio, Rosa.

Politics of Remembering and Forgetting: The Struggle over Colonial Monuments in Mali. Africa Today 52, no. 4(2006): 76-106.

De Swardt, Dorette.

Uitenhage's Anglo-Boer War memorial defaced again. Times Live, 22 June, 2015. Accessed 26 October 2016, http://www.timeslive.co.za/local/2015/06/22/ Uitenhage\%E2\%80\%99s-Anglo-Boer-War-memorial-defaced-again

Escobar, Arturo.

2001. Culture Sits in Places: Reflections on Globalism and Subaltern Strategies of Localization. Political Geography 20, no. 2 (2001): 139-174.

Fabre, Genevieve \& Robert O'Meally.

History and Memory in African American Culture. New York: Oxford University Press, 1994.

Foucault, Michel.

The Archaeology of Knowledge and the Discourse on Language. New York: Pantheon Books, 1972.

Grunebaum, Heidi Peta.

Re-Placing Pasts, Forgetting Presents: Narrative, Place, and Memory in the Time of the Truth and Reconciliation Commission. Research in African Literatures 32, no. 3(2001): 198-212.

Grunebaum, Heidi. (2006) Spectres of the Untold: Memory and History in South Africa after the Truth and Reconciliation Commission. Doctor of Philosophy in History. University of the Western Cape. 
Grunebaum, Heidi.

(2011) Memorializing the Past: everyday life in South Africa after the Truth and Reconciliation Commission. New Jersey: Transaction Publishers.

Hardy, A. A Brief History of Monuments. Future Memories, 2015. Accessed September 2015, http://www.future-memories.org/index.php/en/a-briefhistory-of-monuments.html

Hlatshwayo, Rodgers \& samaYende, Sizwe.

King's Statue Vandalised. News 24, 14 September, 2005. Accessed 26 October 2016, http://www.news24.com/SouthAfrica/News/Kings-statuevandalised-20050914

Johnson, Doyle Paul. 2008.

Symbolic Interaction: Constructing the Social World - and its Participants' Identities. In Contemporary Sociological Theory: An Integrated Multi-Level Approach, edited by Doyle Paul Johnson, 109-134. New York: Springer.

Keet, Andre, Denise Zinn \& Kimberley Porteus.

Mutual vulnerability: A key principle in a humanizing pedagogy in post-conflict societies. Perspectives in Education 27, no. 2(2009):109-119.

Khoza, A.

Paul Kruger statue in Pretoria vandalised again. News24, 11 April, 2015. Accessed 27 October 2016, https://www.news24.com/SouthAfrica/News/Paul-Krugerstatue-in-Pretoria-vandalised-again-20150411

Kros, Cynthia.

Rhodes Must Fall: archives and counter-archives. Critical Arts 29, no. 1 (2015): $150-165$.

Leibowitz, Vicki.

Making Memory Space: Recollection and Reconciliation in Post-Apartheid South African Architecture. Master of Architecture. RMIT University, 2008.

\section{Linden, A.}

Anglo Boer War statue defaced with white paint in East London. Timeslive, 20 April, 2015. Accessed 26 October 2015, https://www.timeslive.co.za/politics/2015-0420-anglo-boer-war-statue-defaced-with-white-paint-in-east-london/

Lindeque, Mia.

Marthinus Wessel Pretorius Andrew Murray Statues Vandalised. Eyewitness News, 11 April, 2015. Accessed 26 October 2016, https://ewn.co.za/2015/04/11/ Martinus-Wessel-Pretorius-Andrew-Murray-statues-vandalised 
Mabeba, Moyahabo.

Statues: what should be done? Capricorn Voice, 28 April, 2015. Accessed 27 October 2016, http://capricornreview.co.za/44111/stat/

Manda, Sihle.

George V statue vandalised again. Independent Online, 30 March, 2015. Accessed 27 October 2016, https://www.iol.co.za/news/south-africa/kwazulu-natal/ george-v-statue-vandalised-again-1838807\#.VTjxs9KqpHw

Mbembe, Achille, Meg Samuelson, Sarah Nuttall and Grace Musila.

Scandal of Beauty: The Cape must embrace its rich mix. Independent Online, 7 June, 2011.[Online]. Accessed February 2016, http://www.iol.co.za/capetimes/ opinion-the-cape-must-embrace-its-rich-mix-1079700

Mbembe, Achille.

Decolonizing Knowledge and the Question of the Archive. Public Lecture. Witwatersrand Institute of Social and Economic Research (WISER), 2015.

Mceachern, Charmaine.

1998. Mapping the Memories: Politics, Place and Identity in the District Six Museum, Cape Town. Social Identities 4, no. 3 (1998): 499-521.

News24. Queen Victoria statue vandalised in PE. 10 April, 2015. Accessed 27 October 2016, http://www.news24.com/SouthAfrica/News/Queen-Victoriastatue-vandalised-in-PE-20150410

Nthite, Tsabeng.

Tshwane's statue target of racist vandalism. Independent Online. 15 July, 2006. Accessed 27 October 2016, http://www.iol.co.za/news/south-africa/tshwanesstatue-target-of-racist-vandalism-285525

Quashie, Kevin.

Black Women, Identity and Cultural Theory: (un)becoming the subject. New Brunswick: Rutgers University Press, 2004.

Snow, David A. 2001.

Extending and Broadening Blumer's Conceptualization of Symbolic Interactionism. Symbolic Interaction 24, no. 3(2001): 367-377.

Subrt, J.

The antinomies of memory. World Congress on Communication and Art. Conference Paper. Australia: 4-7 April, 2013. 
Panofsky, Erwin.

Perspective as Symbolic Form. New York: Zone Books, 1991.

Raborife, Mpho.

Wellington statue of Andrew Murray vandalised. News24.com, 13 April, 2015. Accessed 26 October 2016, https://www.news24.com/SouthAfrica/News/ Wellington-statue-of-Andrew-Murray-vandalised-20150413

Shringapure, Bhakti.

Rage against the monuments. Warscapes, 2015. Accessed 21 May 2016, www. warscapes.com/opinion/rage-against-the-monuments

SouthAfrica.info. 21 monuments for 21 years of freedom, 2015. Accessed

27 October 2016, http://www.southafrica.info/about/history/ monuments-100415.htm\#.WBHuFy196M8

SouthAfrica.com. 1820 Settlers Monument - A Living Memorial, n.d. Accessed 26 October 2016, http://www.southafrica.com/eastern-cape/grahamstown/ settlers-monument/

South African History Online (SAHO). The Castle of Good Hope, oldest surviving building in South Africa, is completed, 2011. Accessed 26 October 2016, http:// www.sahistory.org.za/dated-event/castle-good-hope-oldest-survivingcolonial-building-south-africa-completed

Spies, D.

EFF Damages PE Horse Memorial. News24. 7 April, 2015. Accessed 27 October 2016, http://www.news24.com/SouthAfrica/News/EFF-damages-PE-horsememorial-20150407

Tuan, Yi-Fu.

Space and Place: The Perspective of Experience. London: Edward Arnold Publishers, 1977.

Quashie, Kevin.

Black Women, Identity and Cultural Theory: (un)becoming the subject. New Brunswick: Rutgers University Press, 2004.

Verderey, Katherine.

The political lives of dead bodies: reburial and postsocialist change. New York: Columbia University Press, 1999. 